\title{
Southern Pine Beetle, Dendroctonus frontalis Zimmermann (Insecta: Coleoptera: Scolytidae) ${ }^{1}$
}

\author{
James R. Meeker, Wayne N. Dixon, John L. Foltz, and Thomas R. Fasulo²
}

\section{Introduction}

The southern pine beetle (SPB), Dendroctonus frontalis Zimmermann, is the most destructive insect pest of pine in the southern United States. A recent historical review estimated that SPB caused $\$ 900$ million of damage to pine forests from 1960 through 1990 (Price et al. 1992). This aggressive tree killer is a native insect that lives predominantly in the inner bark of pine trees. Trees attacked by SPB often exhibit hundreds of resin masses (i.e., pitch tubes) on the outer tree bark. SPB feed on phloem tissue where they construct winding S-shaped or serpentine galleries. The galleries created by both the adult beetles and their offspring can effectively girdle a tree, causing its death. SPB also carry, and introduce into trees, blue-stain fungi. These fungi colonize xylem tissue and block water flow within the tree, also causing tree mortality (Thatcher and Conner 1985). Consequently, once SPB have successfully colonized a tree, the tree cannot survive, regardless of control measures.

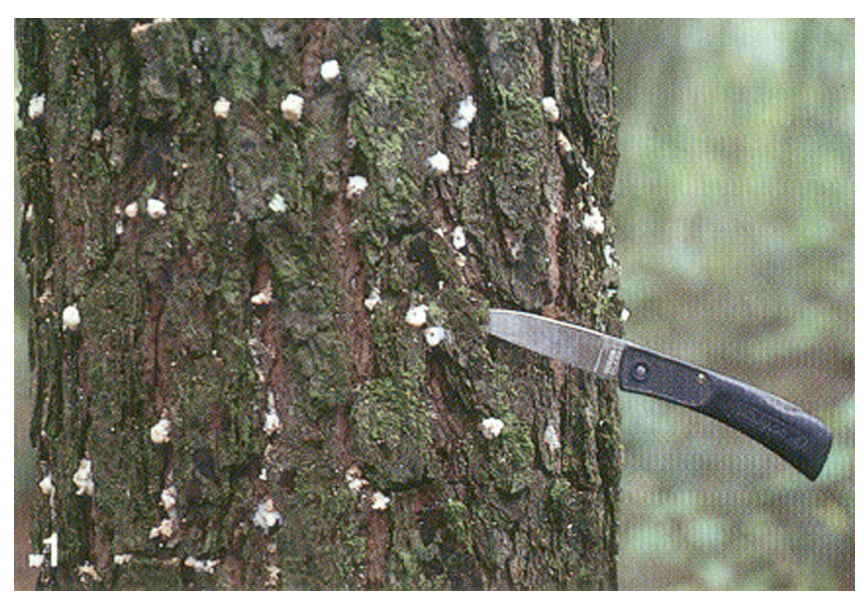

Figure 1. Pitch tubes of the southern pine beetle (SPB), Dendroctonus frontalis Zimmermann, on outer bark. Credits: Division of Plant Industry

When beetle populations are low (endemic), attacks are generally restricted to senescent, stressed or damaged pines; however, epidemics periodically occur (Thatcher et al. 1980). During epidemics, SPB infestations often begin in weakened or injured trees, but the high beetle populations can invade and overcome healthy vigorous trees by attacking in large numbers over a short period of time (Thatcher et al.

1. This document is EENY-176 (originally published as DPI Entomology Circular 369), one of the Featured Creatures series of the Entomology and Nematology Department, Cooperative Extension Service, Institute of Food and Agricultural Sciences, University of Florida. Published: November 2000. Revised: March 2004. This document is also available on Featured Creatures Website at http://creatures.ifas.ufl.edu. Please visit the EDIS Website at http://edis.ifas.ufl.edu. Additional information on these organisms, including many color photographs, is available at the Entomology and Nematology Department website at http://entnemdept.ifas.ufl.edu/.

2. James R. Meeker, Florida Department of Agriculture and Consumer Services, Division of Forestry; Wayne N. Dixon, Florida Department of Agriculture and Consumer Services; John L. Foltz, and Thomas R. Fasulo, Entomology and Nematology Department, University of Florida, Gainesville, FL. 


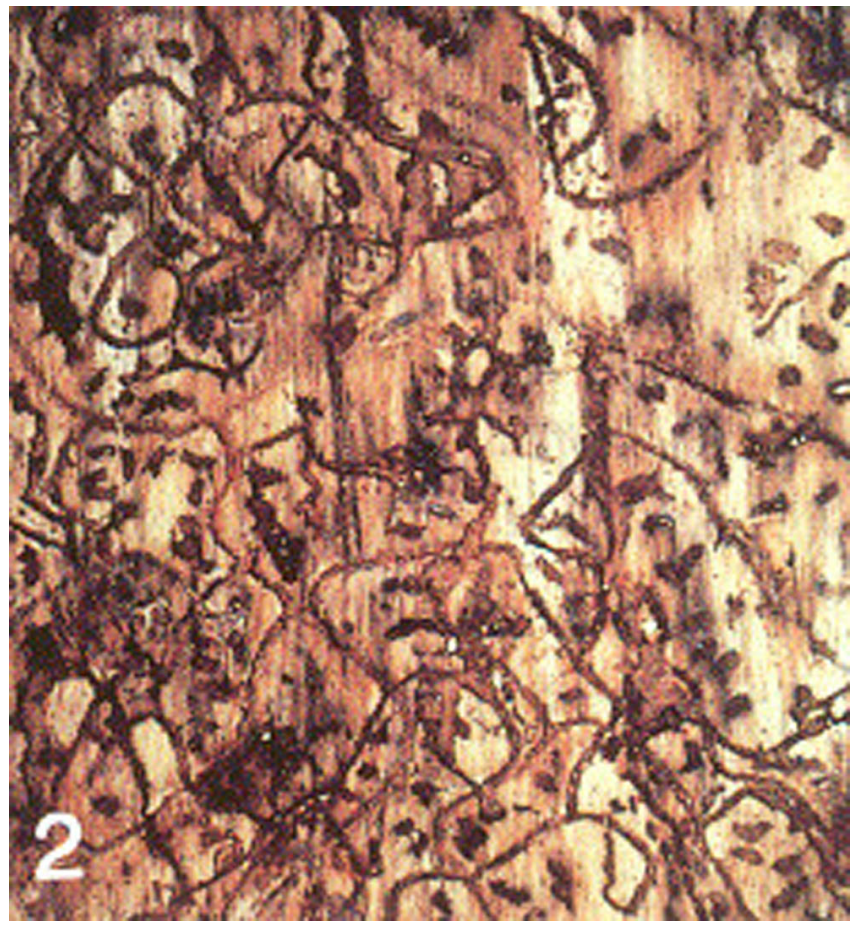

Figure 2. S-shaped galleries of the southern pine beetle (SPB), Dendroctonus frontalis Zimmermann. Credits: Wayne N. Dixon, FDACS, Division of Plant Industry

1980). Widespread and severe tree mortality can occur during epidemics, SPB spots (groups of infested trees) may expand at rates up to $50 \mathrm{ft}$. (15 $\mathrm{m})$ /day, and uncontrolled infestations may grow to thousands of acres in size (Ron Billings, Texas Forest Service, personal communication). SPB attacks are not limited to conventional forest sites; they also may kill high-value trees in yards, parks, and other ornamental settings (Thatcher et al. 1978). Because of the seriousness of SPB infestations, care should be taken not to confuse SPB with the less aggressive but more common pine bark beetles of Florida, the pine engravers (Ips spp.) and the black turpentine beetle (D. terebrans (Olivier)) (Dixon 1984, 1986).

\section{Distribution}

The SPB occurs in a generally continuous distribution across the southern and southeastern United States (AL, AR, DE, FL, GA, KY, LA, MD, MS, NC, OK, SC, TN, TX, VA, WV), roughly coinciding with the distribution of loblolly pine, Pinus taeda L. SPB has occurred as far north as PA and NJ. SPB also occurs from AZ and NM south through Mexico and Central America into northern Nicaragua (Thatcher et al. 1980). Although range maps indicate that SPB may occur throughout the state of Florida, there is no known record of a SPB outbreak south of Hernando County (Chellman and Wilkinson 1975, Price et al. 1992). Infestations, however, have been documented as far south as in Pasco County. SPB is unlikely to occur south of $\mathrm{N}$ $28^{\circ} 15^{\prime}$ latitude in FL, due to the scarcity and/or lack of loblolly pine in the southern half of the state.

\section{Description}

Eggs are ca. 1.5 X $1.0 \mathrm{~mm}$, oval in shape, shiny, opaque and pearly white.

Larvae range in size from 2 to $7 \mathrm{~mm}$ in length and are wrinkled, legless, yellowish-white, with reddish-colored heads.

Pupae have the same general color of larvae and the same general form and size of adults.

Adults are 2 to $4 \mathrm{~mm}$ in length, short-legged, cylindrical and brown to black in color. The broad and prominent head has a distinct notch or frontal groove on male beetles. Females possess a broad, elevated, transverse ridge (mycangium) along the anterior pronotum. The rear end or abdomen of adults is rounded. Callow (new) adults progressively change in color from yellowish-white to yellowish-brown to reddish-brown to finally become dark brown (Thatcher et al. 1980).

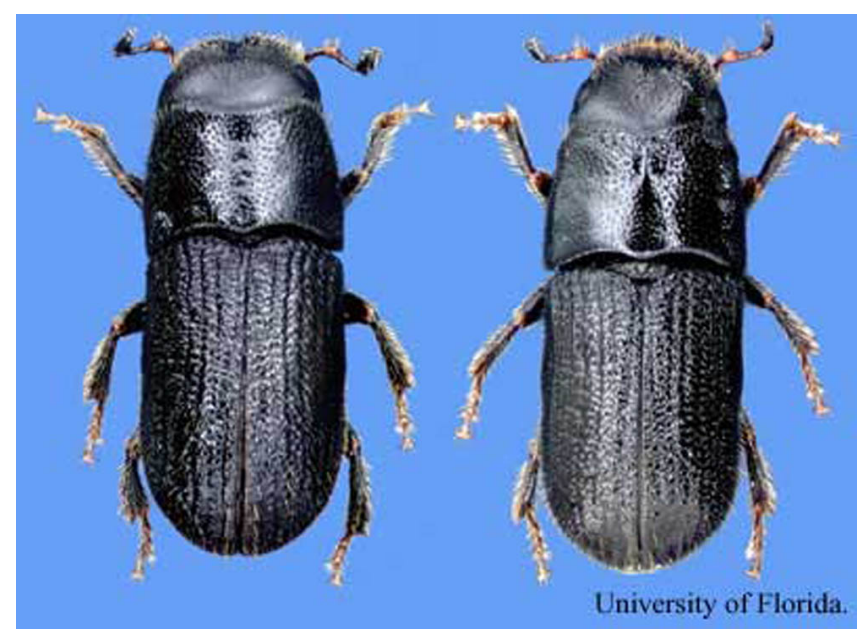

Figure 3. Dorsal view of southern pine beetles,

Dendroctonus frontalis Zimmermann, with male on the left and female on the right. Credits: David T. Almquist, University of Florida 


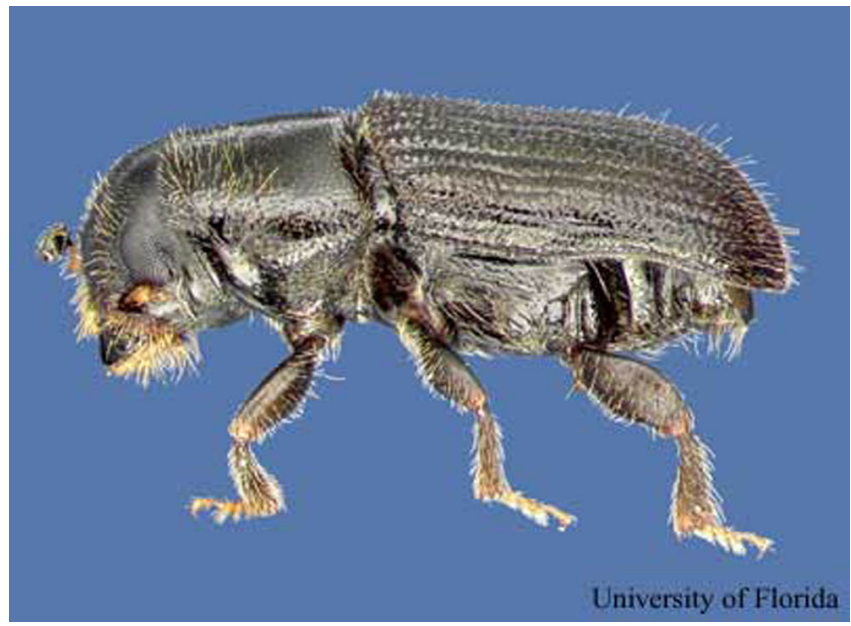

Figure 4. Lateral view of southern pine beetle, Dendroctonus frontalis Zimmermann. Credits: David T. Almquist, University of Florida

\section{Biology}

Adult female SPB are responsible for host selection (Thatcher et al. 1980). After locating a suitable host tree, a female beetle bores through the bark to initiate gallery construction in the inner phloem. Soon after initial attack, females emit an aggregation pheromone (frontalin), which attracts males and more females to the tree. This pheromone, in conjunction with host odors stemming from resin exudation at attack points, attracts more SPB to the tree. The aggregation of beetles results in a mass attack over a short period of time (Dixon and Payne 1979). Mass-attacking enables the beetles to overcome the natural defense mechanism of the tree, its resin production system. Resin under pressure within the tree can successfully force out or pitch out beetles if there are only a few beetles and the tree is relatively healthy. Mass-attacking SPB deplete the resin production capabilities of the tree causing resin flow to cease, after which point the tree is easily overcome. Mating soon takes place and females begin to construct long, winding S-shaped galleries that cross over each other. These galleries are packed with frass and boring material by males. Up to 30 eggs are deposited in niches along each gallery. Parent adults may then reemerge from the tree one to 20 days following oviposition and proceed to attack the same tree or another (Thatcher et al. 1980).

Eggs hatch three to nine days following oviposition. Larvae feed in the inner phloem and construct winding galleries perpendicular to parent egg galleries. As larvae develop, they progressively tunnel towards the outer bark. During the fourth and final larval instar, the legless grubs move to the outer bark and form a pupal cell. The pupal stage lasts five to 17 days, before insects turn into callow adults. Callow adults remain under the bark for six to 14 days while their cuticle hardens and darkens. The young adults then bore an exit tunnel directly through the outer bark, leaving an open "shot" hole behind. Generally, the emerging beetles fly off to attack another tree (Thatcher et al. 1980). Adult beetles are capable of flying ca. 2 miles $(3 \mathrm{~km})$, and it is estimated that during dispersal phases, half of the beetles travel more than 0.43 mile $(0.69 \mathrm{~km})$ (Turchin and Thoeny 1993). The duration from egg to adult ranges from 26 to 60 days. There may be as many as seven to nine generations per year in Florida.

SPB exhibit behavioral changes with changes in the seasons. In the South, emergence of overwintering beetles has been correlated with the blossoming of flowering dogwood (Cornus florida L.) in the spring (Thatcher and Barry 1982). This spring emergence represents the primary dispersal phase of SPB, during which beetles often initiate multiple and widespread infestations. During the summer months, beetle development is hastened and infestations tend to proliferate and expand very rapidly. SPB populations undergo a secondary dispersal phase in the fall, tending to produce scattered small infestations. These infestations typically remain small and dispersed during the winter months when beetle activity is slowest (Thatcher et al. 1980).

\section{Hosts}

SPB will infest and kill all species of pine within its distribution (Thatcher et al. 1980). In the southern United States, the preferred hosts are loblolly pine, shortleaf pine (Pinus echinata Mill.), pond pine ( $P$. serotina Michx.), and Virginia pine (P. virginiana Mill.) (Thatcher and Barry 1982). In Florida, SPB will also readily attack and kill spruce pine ( $P$. glabra Walter), and sand pine ( $P$. clausa (Chapman ex Engelm.) Vasey ex Sarg.) (Chellman and Wilkinson 1975). Slash pine (P. elliottii Engelm.) and longleaf pine ( $P$. palustris Mill.) are generally considered to be more resistant to SPB attacks, but during 
outbreaks even healthy trees of these species can be successfully colonized (Belanger et al. 1993; Belanger and Malac 1980).

\section{Outbreaks}

Outbreaks of this insect tend to be cyclical in occurrence. Outbreaks have occurred on six to 12 year intervals and generally last for two to three years in areas where SPB has long been a problem. Southwide, the time between outbreaks has decreased while the intensity and distribution of each outbreak has increased since 1960 (Belanger et al. 1993; Price et al. 1992). In Florida, infestations have been relatively few and small in the past (Chellman and Wilkinson 1975, 1980; Dixon, unpublished data). Many factors are involved in the development of outbreak conditions, such as the abundance and susceptibility of preferred hosts, and weather patterns and events (e.g., drought, storms).

Historically, Florida has not experienced many destructive SPB episodes probably because of the lack of large contiguous areas of loblolly and shortleaf pine in susceptible stages. However, an epidemic in and around Gainesville in Alachua County during 1994, warranted a reconsideration of the serious threat SPB poses to Florida's pine forests. Gainesville is experiencing an even worse outbreak in the urban and wildland urban interface areas than in 1994-95. Of the more than 400 infestations already detected throughout the county, approximately half have been located within the city limits of Gainesville. Scores of landowners/homeowners have spent hundreds to thousands of dollars attempting to tackle the problem (Anonymous 2001). In 2000, the state issued a declaration of emergency due to a southern pine beetle epidemic in Hernando County. Since then the emergency has been expanded to 25 counties. Southern pine beetle surveys, once conducted on an annual basis by the Florida Division of Forestry, are now being taken monthly.

Forest inventory statistics indicate that from 1970 to 1995 , the acreage of loblolly pine forest in Florida more than doubled from a mere 337,000 ac. (136,380 ha) to more than 807,300 ac. (326,704 ha) (Brown 1999; Knight 1969; McClure 1970). The current acreage of loblolly pine also represents an all-time high since inventory statistics were reported in 1949. This alarming increase, and current level of preferred host material suggests that SPB epidemics in Florida may be more frequent, widespread and destructive in the future (Dixon, unpublished data).

\section{Survey Detection}

Often the first noticeable indication of SPB attack is foliage discoloration. Crowns of dying pines change color from green to yellow to red before turning brown and falling from the tree. The time it takes for these changes varies seasonally. Frequently, by the time crowns are red the beetles have already vacated the tree. The earliest signs of possible SPB-attack is the presence of brownish-orange boring dust and tiny white pitch pellets accumulating at the base of the tree, in bark crevices, in nearby spider webs, and on understory foliage. A more noticeable indication of SPB attack is the presence of multiple popcorn size lumps of pitch (i.e., pitch tubes) on the outer bark of pine stems. These pitch tubes may occur from near ground level up to 60-ft. (18-m) high, but may not develop at all on trees severely weakened before beetle attack. The most diagnostic sign of SPB activity is the presence of the winding S-shaped galleries that cross over each other and are packed with boring dust and frass. These can be found by exposing a portion of the inner bark beneath pitch tubes or by removing a section of bark. Another sign of possible SPB activity is the presence of clear shot-like holes (ca. $1 \mathrm{~mm}$ in dia.) on the exterior bark surfaces where SPB have emerged (Billings and Pase 1979, Thatcher and Conner 1985). SPB infestations typically kill groups of trees, which allows for prioritizing investigations of suspect mortality.

\section{Prevention and Control}

Preventative strategies for homeowners and forest managers include:

- planting more resistant species such as longleaf pine and slash pine in place of loblolly pine and planting loblolly pine only on appropriate sites (i.e., right tree for the right place); 
- thin overstocked, dense or stagnant stands to a basal area of 80 sq. ft. per ac. (18 sq. m per ha) or less;

- maintain at least $25 \mathrm{ft} .(8 \mathrm{~m})$ distance between mature pines in urban settings;

- promote tree diversity in the landscape;

- remove damaged pines;

- maintain tree health and vigor by supplemental watering during extended dry periods;

- minimize construction and logging damage to pines and avoid soil compaction during operations;

- minimize changes in soil and water levels around pines;

- conduct logging or land clearing operations during coolest winter months;

- shorten rotation ages to less than 30 years; and

- apply an approved insecticide to high-value trees when the threat of SPB attack is imminent and the potential benefits outweigh the costs and risks of chemical use.

Remedial control measures to suppress existing infestations are limited. Generally, the most effective and desirable approach is to remove and process all SPB-infested pines as soon as possible. Trees can be salvaged and SPB will be destroyed in the milling process. If trees cannot be salvaged, the bark should be destroyed, buried, or chipped and composted. In forested settings, it is recommended that a 50 to 100 ft. ( 15 to $30 \mathrm{~m}$ ) buffer strip of green uninfested trees also be removed to ensure that recently infested trees are not left behind.

Where tree removal is not feasible, infested stems can be felled, bucked and hand-sprayed with an approved insecticide. Where none of the above approaches is feasible, infested trees, with or without a buffer strip, may be simply felled toward the center of the spot. This cut-and-leave approach has had limited use with variable results (Belanger and Malac 1980; Swain and Remion 1981; Thatcher et al. 1978). Much research continues toward the development of effective methods of utilizing semiochemicals to suppress SPB infestations, but as yet, operational uses are still on the horizon (Billings and Upton 1993; Hayes and Strom 1994; Payne and Billings 1989).

\section{Selected References}

Anonymous. (April 2001). 2001 Southern pine beetle trapping survey for Florida. Florida Division of Forestry. http://www.fl-dof.com/Conservation/forest_health/ SPB2001/ (5 July 2001).

Belanger, R.P., R.L. Hedden, and P.L. Lorio, Jr. 1993. Management strategies to reduce losses from the southern pine beetle. Southern Journal of Applied Forestry 17: 150-154.

Belanger, R.P., and B.F. Malac. 1980.

Silviculture can reduce losses from the southern pine beetle. USDA Forest Service, Combined Forest Pest Research Development Program. Handbook No. 576. $17 \mathrm{p}$.

Billings, R.F., and H.A. Pase, III. 1979. A field guide for ground checking southern pine beetle spots. USDA Forest Service, Combined Forest Pest Research Development Program. Handbook No. 558. $19 \mathrm{p}$.

Billings, RF., and W.W. Upton. 1993.

Effectiveness of synthetic behavioral chemicals for manipulation and control of southern pine beetle infestations in East Texas. USDA Forest Service, Southern Forest Experiment Station. General Technical Report: 555-568.

Brown, M.J. 1999. Florida's forests, 1995. Resour. Bull. SRS-48. Asheville, NC: U.S. Department of Agriculture, Forest Service, Southern Research Station. 83 p.

Chellman, C.W., and R.C. Wilkinson. 1975. Recent history of southern pine beetle, Dendroctonus frontalis Zimm., (Col.; Scolytidae) in Florida. Florida Entomologist 58: 22.

Chellman, C.W., and R.C. Wilkinson. 1980. Southern pine beetle outbreaks in Florida since 1974. Florida Entomologist 63: 515. 
Dixon, W.N. 1984. lps engraver beetles. FDACS, Division of Forestry. Forest and Shade Tree Pests Leaflet No. 2. 2 p.

Dixon, W.N. 1986. Black turpentine beetle. FDACS, Division of Forestry. Forest and Shade Tree Pests Leaflet No. 4. 2 p.

Dixon, W.N., and T.L. Payne. 1979. Aggregation of Thanasimus dubius on trees under mass- attack by the southern pine beetle. Environmental Entomology 8: $178-181$.

Fidgen, J. (May 2000). Southern pine beetle information directory. http://www.ento.vt.edu/ salom/SPBinfodirect/ spbinfodirect.html (5 July 2001).

Fidgen, J. (July 2001). Southern pine beetle Internet control center. http://whizlab.isis.vt.edu/servlet/sf/spbicc/ (5 July 2001).

Foltz, J.L., and J.R. Meeker. (June 4, 2001). The southern pine beetle in Florida. http://eny3541.ifas.ufl.edu/pbb/spb_info.htm (5 July 2001).

Hayes, J.L., and B.L. Strom. 1994. 4-Allyanisole as an inhibitor of bark beetle (Coleoptera: Scolytidae) congregation. Journal of Economic Entomology 87: 1548-1556.

Knight, H.A. 1969. Forest statistics for northwest Florida, 1969. USDA Forest Service, Southeastern Forest Experiment Station. Resource Bulletin SE-14. $35 \mathrm{p}$.

McClure, J.P. 1970. Forest statistics for northeast Florida, 1970. USDA Forest Service, Southeastern Forest Experiment Station. Resource Bulletin SE-15. $33 \mathrm{p}$.

Payne, T.L., and R.F. Billings. 1989. Evaluation of (S)-verbenone applications for suppressing southern pine beetle (Coleoptera: Scolytidae) infestations. Journal of Economic Entomology 82: 1702-1708.

Price, T.S., C. Doggett, J.L. Pye, and T.P. Holmes, eds. 1992. A history of southern pine beetle outbreaks in the southeastern United States. Sponsored by the Southern Forest Insect Work Conference. The Georgia Forestry Commission, Macon, GA. 65 p.

Swain, K.M., Sr., and M.C. Remion. 1981. Direct control methods for the southern pine beetle. USDA Forest Service, Combined Forest Pest Research Development Program. Handbook No. 575. $15 \mathrm{p}$.

Thatcher, R.C., and P.J. Barry. 1982. Southern pine beetle. USDA Forest Service, Washington, D.C. Forest and Disease Leaflet No. 49.7 p.

Thatcher, R.C., and M.D. Conner. 1985. Identification and biology of southern pine bark beetles. USDA Forest Service, Washington D.C. Handbook No. 634. 14 p.

Thatcher, R.C., J.E. Coster, and T.L. Payne. 1978. Southern pine beetles can kill your ornamental pine. USDA Forest Service, Combined Forest Pest Research Development Program, Washington, D.C. Home and Garden Bulletin No. 226. 15 p.

Thatcher, R.C., J.L. Searcy, J.E. Coster, and G.D. Hertel, eds. 1980. The southern pine beetle. USDA, Expanded Southern Pine Beetle Research and Application Program, Forest Service, Science and Education Administration, Pineville, LA. Technical Bulletin 1631. 265 p.

Turchin, P., and W.T. Thoeny. 1993. Quantifying dispersal of southern pine beetles with mark- recapture experiments and a diffusion model. Ecological Applications 3: 187-198. 